\title{
Secondary School Teachers Self-Perception of Digital Teaching Competence in Spain Following COVID-19 Confinement
}

\author{
Jorge-Manuel Prieto-Ballester ${ }^{1}$ (D) Francisco-Ignacio Revuelta-Domínguez ${ }^{2, *}$ (D) \\ and María-Inmaculada Pedrera-Rodríguez ${ }^{2}$ \\ 1 Faculty of Education, University of La Rioja, 26006 Logroño, Spain; jorgemanuel.prieto@unir.net \\ 2 Department of Educational Sciences, Faculty of Teacher Training, University of Extremadura, \\ 10003 Cáceres, Spain; inmapedrera@unex.es \\ * Correspondence: fird@unex.es
}

check for updates

Citation: Prieto-Ballester, J.-M.; Revuelta-Domínguez, F.-I.; Pedrera-Rodríguez, M.-I. Secondary School Teachers Self-Perception of Digital Teaching Competence in Spain Following COVID-19 Confinement. Educ. Sci. 2021, 11, 407. https: / / doi.org/10.3390/ educsci11080407

Academic Editors:

Jesús Valverde-Berrocoso,

María Rosa Fernández-Sánchez and Neil Gordon

Received: 28 June 2021

Accepted: 30 July 2021

Published: 5 August 2021

Publisher's Note: MDPI stays neutral with regard to jurisdictional claims in published maps and institutional affiliations.

Copyright: (c) 2021 by the authors. Licensee MDPI, Basel, Switzerland. This article is an open access article distributed under the terms and conditions of the Creative Commons Attribution (CC BY) license (https:/ / creativecommons.org/licenses/by/ $4.0 /)$.

\begin{abstract}
The education system has become even more complex following the global pandemic, which saw face-to-face teaching transition to virtual teaching. To cope with this abrupt transition, it is essential that teachers have a sufficient level of digital teaching competence. This article aims to increase awareness of teachers' self-perception of their digital teaching competences in the educational field. Specifically, this study explores Spanish secondary school teachers' knowledge and use of different ICT tools by evaluating their competence based on different areas proposed by The National Institute of Technology and Professional Development (Instituto Nacional de Tecnologías Educativas y de Formación del Profesorado, INTEF), Madrid, Spain. From the results of the questionnaires, we have determined that teachers consider themselves to have an upper intermediate level of digital teaching competence, although there are still shortcomings that need to be addressed in order to improve this level of competence, and its true integration in the teaching-learning process.
\end{abstract}

Keywords: digital teaching competence; information and communication technology; blendedlearning; COVID-19; emergency remote teaching

\section{Introduction}

The use of information and communication technology (ICT) resources has changed the way we relate to each other [1]. These advances in technology have also been transferred to the education system, providing teachers with material and immaterial resources that have allowed them to delve deeper into the teaching-learning process, which facilitates their work.

Not only is digital teaching competence (DTC) important in the educational field, but digitization and competence in the use of ICTs is a key element when working in any field of work. Digital competence should help to achieve the highest level of performance in professional tasks [2], but only $26 \%$ of organizations are prepared to face the changes brought about by new technologies [3].

This relevant finding has not been reflected in data on citizens' digital competence. In $2015,44.5 \%$ of the EU population aged 16-74 did not have sufficient digital skills to manage socially and economically [4].

The importance of DTC has been considered by institutions as a basic competence required by pupils, and given that teachers are faced with a student body that joins the education system with a high level of use of ICTs [5], it should be a fundamental competence for teachers.

However, if the use of ICT resources was previously seen as an important element both in educational development and in the workplace, recent global events have shown that the use of ICTs must be a fundamental requirement for dealing with exceptional situations, such as the current COVID-19 situation, which could change the educational and professional models we have had until now. This pandemic has caused teaching, 
which for the most part was carried out face-to-face, to become virtualized at a rapid pace for all levels of the whole educational community. In the literature, this phenomenon has been referred to as "Emergency Remote Teaching (ERT)" [6].

The necessity to virtualize teaching has exposed many shortcomings that may have been thought overcome [7], and which will surely be addressed by the academic world soon [8-13].

Today's teachers cannot be classified as digital natives, as their ICT skills are based on the knowledge that they have had to learn throughout their lives. This raises many doubts as to whether the level of competence they have achieved is high enough to supervise a process in which the real protagonists have a higher level [14]. In fact, for teachers, there is still a long way to go to achieve sufficient initial training, as well as the professional development that this may involve $[15,16]$.

In order to overcome these shortcomings, it is important to define a model so that teachers can acquire this competence and overcome the existing gap between their own knowledge and the actual implementation of this knowledge in the teaching methods [2,14], and also to overcome the numerous complaints about the type of teaching that is being given, supposedly in a virtual manner, which in many cases simply consists of sharing notes on a virtual campus. Furthermore, it is necessary for teachers to acquire a series of skills that will enable them to keep up with the new reality demanded by students [17-19].

Within the educational field, it is not enough to consider digital competence as an element that allows access to the use of ICTs; it must also be considered as a key element of participation in today's society [20].

In order to establish a strategy for the teaching staff to acquire digital teaching competences, it is imperative to know their level of competence beforehand [16,21-26], in order to be able to provide training and to improve the acquisition of digital teaching competence.

It should not be forgotten that competence goes far beyond the possession of knowledge. The need for digital competences to be closely related to the knowledge of the subject and the pedagogy used must be taken into account, as well as the fact that it is not possible to analyze each dimension independently if we want to discuss a genuine use of digital competence in the eyes of students [27-31].

When it comes to measuring digital teaching competence, both authors [32] and institutions recognize its importance, and institutions are aware of the need to measure this competence. In fact, the European Commission, in the 'opening up education' framework, highlights the importance of developing '... digital competence frameworks and selfassessment tools for students, teachers and organizations' [33].

This importance is reflected in the fact that the European Commission itself proposes a self-assessment model for citizens' digital competences in which five assessment areas are recognized, such as information processing, communication, content creation, security, and problem-solving [34]. In this sense, INTEF (National Institute of Technology and Professional Development of Spain) determines that there are the same five competence areas and a total of 21 competences, measured on the basis of six levels of digital competence achievement by the teaching staff [20].

INTEF is the institution that has identified and defined the digital teaching competences in Spain through its common framework reports. INTEF [20] defines digital teaching competence as 'the set of competences that 21st century teachers must develop to improve the efficacy of their educational practice and for their own ongoing professional development'. These competences are determined in the common framework of digital competence for teachers, which establishes the key digital competences for the teaching staff to adapt to the needs of the present and the future [20]. Due to the administrative composition of Spain, INTEF has tried to reach a consensus on the common framework of digital competence for teachers with Autonomous Communities. In any case, and due to Spain's administrative composition, some Autonomous Communities have developed their own models for measuring digital competence, such as Extremadura, the Basque Country, and Catalonia; others have referred directly to INTEF, such as Asturias, Galicia, 
and Navarre. This disparity between the Autonomous Communities has created certain differences when it comes to measuring, comparing, and identifying needs [35].

This article presents the selected questionnaire and the final sample that participated in the study in the Materials and Methods section. In the Results section, we include both a general data analysis and one that is differentiated by areas, and the reader will find tables of the percentage values of responses to the items by gender. Subsequently, the open-ended questions that enrich the results are analyzed.

\section{Materials and Methods}

The main objective of this study is to discover Spanish secondary school teachers' self-perception of their level of digital teaching competence. In order to do so, teachers are evaluated and classified according to the different levels of digital teaching competence, their training deficiencies in relation to digital teaching competence are identified, and education policies aimed at improving digital teaching competence are proposed.

The following research questions have been posed:

(1) Have teachers perceived themselves as digitally competent to deliver ERT? [36].

(2) Which actions have teachers carried out and which technologies have they used?

\subsection{Sample}

The study was carried out on secondary education and sixth form teaching staff of public, private, and state-subsidized schools in Spain.

A total of 208 questionnaires were collected, of which 31 were initially discarded because they were submitted by teaching staff working outside Spain, and thus outside the scope of this study. This sample is non-representative and unintentional. The questionnaire was distributed through the usual channels of communication with schools.

The final sample is made up of 177 participants, of which $36.7 \%$ are male and $63.3 \%$ are female. The mean age of the group is 45 (with a standard deviation of 8.36 ) years.

\subsection{Digital Teaching Competence (DTC) Questionnaire}

The questionnaire created by Tourón et al. [25] was used as a starting point for the data collection and assessment of teachers' impression of digital teaching competence, which was published in the article 'Construct validation of a questionnaire to measure teachers' digital competence (TDC)'. This questionnaire was chosen because it has been validated by more than 400 teachers, it is a fairly current questionnaire, and it corresponds perfectly with the object of the study. The aforementioned questionnaire contains a total of 54 items (see Table 1) grouped into five categories (information, communication, content creation, security, and problem-solving) in which the teachers' knowledge and level of use of ICTs are assessed on a seven-point Likert scale (where 1 represents 'I don't use it or I don't know it', and 7 represents 'I use it frequently or I know it well').

Table 1. Descriptive statistics of the questionnaire items.

\begin{tabular}{|c|c|c|c|c|}
\hline \multirow{2}{*}{ Items } & \multicolumn{2}{|c|}{ Knowledge } & \multicolumn{2}{|c|}{ Use } \\
\hline & $\mathbf{M}$ & SD & $\mathbf{M}$ & SD \\
\hline $\begin{array}{l}\text { 1. Internet browsing strategies (e.g., searches, filters, using } \\
\text { operators, specific commands, using search operators, etc.). }\end{array}$ & 5.51 & 1.55 & 5.38 & 1.59 \\
\hline 2. Open educational resources (OERs). & 4.41 & 1.80 & 3.95 & 1.79 \\
\hline 3. Projects in my school relating to digital technology. & 4.83 & 1.96 & 4.43 & 2.02 \\
\hline $\begin{array}{l}\text { 4. Solutions for management and storage in the 'cloud', sharing files, } \\
\text { granting access privileges, etc. (e.g., Drive, OneDrive, Dropbox and } \\
\text { others). }\end{array}$ & 5.92 & 1.51 & 5.75 & 1.63 \\
\hline $\begin{array}{l}\text { 5. Systems for protecting devices and documents (access control, } \\
\text { privileges, passwords, etc.). }\end{array}$ & 5.16 & 1.80 & 4.95 & 1.89 \\
\hline
\end{tabular}


Table 1. Cont.

\begin{tabular}{|c|c|c|c|c|}
\hline \multirow{2}{*}{ Items } & \multicolumn{2}{|c|}{ Knowledge } & \multicolumn{2}{|c|}{ Use } \\
\hline & $\mathbf{M}$ & SD & $\mathbf{M}$ & SD \\
\hline $\begin{array}{l}\text { 6. Strategies for managing information (using tags, recovering } \\
\text { information, classification, etc.). }\end{array}$ & 4.58 & 1.90 & 4.19 & 1.95 \\
\hline 7. The interactive whiteboard software in my centre. & 4.65 & 1.97 & 3.92 & 2.01 \\
\hline $\begin{array}{l}\text { 8. Software available in my school (e.g., marks, attendance, } \\
\text { communication with families, content, evaluating tasks, etc.). }\end{array}$ & 5.78 & 1.59 & 5.55 & 1.69 \\
\hline $\begin{array}{l}\text { 9. Basic solutions for technical problems resulting from the use of } \\
\text { digital tools. }\end{array}$ & 5.05 & 1.84 & 4.81 & 1.90 \\
\hline $\begin{array}{l}\text { 10. Online communication tools: forums, instant messaging, chats, } \\
\text { videoconferencing, etc. }\end{array}$ & 5.53 & 1.47 & 5.73 & 1.58 \\
\hline $\begin{array}{l}\text { 11. Tools for storing and managing shared files and content (e.g., } \\
\text { Drive, Box, Dropbox, Office 365, etc.). }\end{array}$ & 5.91 & 1.49 & 5.77 & 1.61 \\
\hline 12. Tools for creating voice recordings (podcasts). & 4.62 & 1.99 & 3.64 & 2.11 \\
\hline $\begin{array}{l}\text { 13. Recycling points to reduce the environmental impact of } \\
\text { technological waste on the environment (unused devices, mobile } \\
\text { phones, printer toner, batteries, etc.). }\end{array}$ & 4.51 & 2.01 & 4.11 & 2.03 \\
\hline 14. Tools that help respond to diversity in the classroom. & 4.30 & 1.87 & 3.90 & 1.84 \\
\hline $\begin{array}{l}\text { 15. Basic rules for behaviour and etiquette in internet } \\
\text { communication in the educational context. }\end{array}$ & 5.09 & 1.85 & 4.94 & 1.89 \\
\hline 16. Tools for creating presentations. & 5.71 & 1.55 & 5.46 & 1.61 \\
\hline $\begin{array}{l}\text { 17. Social networks, learning communities, etc., for sharing } \\
\text { educational information and content (e.g., Facebook, Twitter, } \\
\text { Google+, or others). }\end{array}$ & 5.84 & 1.54 & 5.21 & 1.83 \\
\hline 18. Specific channels for selecting teaching videos. & 5.13 & 1.76 & 4.83 & 1.85 \\
\hline 19. Tools for content based on augmented reality. & 3.24 & 2.02 & 2.39 & 1.68 \\
\hline $\begin{array}{l}\text { 20. Rules or criteria for critically evaluating the content of a website } \\
\text { (updates, citations, sources). }\end{array}$ & 4.27 & 1.96 & 3.77 & 1.91 \\
\hline 21. Spaces for me to train and update my digital competencies. & 5.16 & 1.76 & 4.74 & 1.86 \\
\hline 22. The potential of ICT for planning and creating new products. & 5.02 & 1.89 & 4.43 & 2.03 \\
\hline 23. Ways to manage digital identities in the educational context. & 3.96 & 1.97 & 3.57 & 1.97 \\
\hline $\begin{array}{l}\text { 24. Strategies for searching for information in different media or } \\
\text { formats (text, video, etc.) to find and select information. }\end{array}$ & 5.33 & 1.68 & 5.22 & 1.77 \\
\hline $\begin{array}{l}\text { 25. Tools for carrying out student evaluation, mentoring, or } \\
\text { monitoring. }\end{array}$ & 5.22 & 1.76 & 4.95 & 1.81 \\
\hline $\begin{array}{l}\text { 26. Basic computer maintenance tasks to avoid possible operational } \\
\text { problems (e.g., updates, cleaning cache or disc, etc.). }\end{array}$ & 4.84 & 2.03 & 4.59 & 2.10 \\
\hline $\begin{array}{l}\text { 27. Ways of eliminating data/information, for which you are } \\
\text { responsible, about yourself or third parties. }\end{array}$ & 4.57 & 2.08 & 4.32 & 2.09 \\
\hline 28. Tools for producing QR codes (Quick Response). & 4.46 & 2.27 & 3.60 & 2.29 \\
\hline 29. Protecting devices against threats from viruses, malware, etc. & 4.68 & 2.02 & 4.60 & 2.06 \\
\hline $\begin{array}{l}\text { 30. Tools to facilitate learning such as infographics, interactive } \\
\text { graphs, concept mapping, time lines, etc. }\end{array}$ & 5.01 & 1.98 & 4.59 & 1.98 \\
\hline $\begin{array}{l}\text { 31. Ways to keep up to date with the use of new devices, apps, and } \\
\text { tools. }\end{array}$ & 5.07 & 1.80 & 4.75 & 1.85 \\
\hline $\begin{array}{l}\text { 32. Rules about the responsible and healthy use of digital } \\
\text { technologies. }\end{array}$ & 5.10 & 1.78 & 4.83 & 1.81 \\
\hline
\end{tabular}


Table 1. Cont.

\begin{tabular}{|c|c|c|c|c|}
\hline \multirow{2}{*}{ Items } & \multicolumn{2}{|c|}{ Knowledge } & \multicolumn{2}{|c|}{ Use } \\
\hline & M & SD & M & SD \\
\hline $\begin{array}{l}\text { 33. Other people's educational experiences or research that might } \\
\text { provide me with content or strategies. }\end{array}$ & 4.79 & 1.82 & 4.49 & 1.91 \\
\hline 34. Sources for finding laws concerning copyright and licences. & 4.32 & 2.02 & 3.97 & 2.02 \\
\hline $\begin{array}{l}\text { 35. Shared and collaborative learning tools (e.g., blogs, wikis, } \\
\text { specific platform such as Edmodo or others). }\end{array}$ & 5.04 & 2.03 & 4.52 & 2.07 \\
\hline $\begin{array}{l}\text { 36.Tools for recovering files that are deleted, damaged, inaccessible, } \\
\text { have formatting errors, etc. }\end{array}$ & 3.64 & 2.00 & 3.27 & 1.90 \\
\hline 37. Tools assessment tests. & 4.92 & 1.85 & 4.55 & 1.92 \\
\hline $\begin{array}{l}\text { 38. The basic logic of programming, comprising the structure, and } \\
\text { basic modification of digital devices and their set-up. }\end{array}$ & 3.82 & 2.10 & 3.47 & 2.12 \\
\hline $\begin{array}{l}\text { 39. Protecting information relating to people in your immediate } \\
\text { surroundings (colleagues, students, etc.). }\end{array}$ & 4.57 & 1.99 & 4.41 & 2.00 \\
\hline $\begin{array}{l}\text { 40. Creative didactic activities for developing students' digital } \\
\text { competency. }\end{array}$ & 4.96 & 1.83 & 4.61 & 1.84 \\
\hline $\begin{array}{l}\text { 41. The compatibility of peripherals (microphones, headphones, } \\
\text { printers, etc.) and connectivity requirements. }\end{array}$ & 5.05 & 1.93 & 4.91 & 1.97 \\
\hline $\begin{array}{l}\text { 42. Options for combining digital and non-digital technology to find } \\
\text { solutions. }\end{array}$ & 5.18 & 1.78 & 4.99 & 1.79 \\
\hline $\begin{array}{l}\text { 43. Ways of controlling technology use when it becomes a } \\
\text { distraction. }\end{array}$ & 3.99 & 1.94 & 3.64 & 1.82 \\
\hline $\begin{array}{l}\text { 44. Criteria for evaluating the reliability of the sources of } \\
\text { information, data, digital content, etc. }\end{array}$ & 4.43 & 1.86 & 4.20 & 1.88 \\
\hline 45. Digital resources adapted to the educational centre's project. & 4.63 & 1.93 & 4.35 & 1.92 \\
\hline 46. Basic energy-saving measures. & 4.64 & 1.97 & 4.39 & 1.90 \\
\hline 47. Tools rubrics. & 4.44 & 2.08 & 4.01 & 2.07 \\
\hline 48. Ways of solving problems among peers. & 4.11 & 1.94 & 3.71 & 2.00 \\
\hline $\begin{array}{l}\text { 49. Different types of licences for publishing my content (copyright, } \\
\text { copyleft, and creative commons). }\end{array}$ & 4.24 & 2.21 & 3.49 & 2.19 \\
\hline 50. Tools to create teaching videos. & 4.85 & 1.90 & 4.32 & 1.96 \\
\hline 51. Tools that help gamify learning. & 4.33 & 2.04 & 3.70 & 2.06 \\
\hline $\begin{array}{l}\text { 52. Tools for reworking or enriching content in different formats } \\
\text { (e.g., texts, tables, audio, images, videos, etc.). }\end{array}$ & 5.18 & 1.81 & 4.94 & 1.87 \\
\hline 53. How to maintain a balanced attitude towards technology use. & 5.65 & 1.72 & 4.52 & 1.71 \\
\hline 54. Spaces for sharing files, images, work, etc. & 5.56 & 1.66 & 5.40 & 1.71 \\
\hline
\end{tabular}

Source: Own elaboration.

In addition, the questionnaire was enriched with a series of open-ended questions that could provide us with more information on the effects of confinement on teachers when carrying out their work (see Table 2). 
Table 2. Final questions.

\begin{tabular}{c}
\hline Open-Ended Questions \\
\hline Have you perceived a change in your own digital competence as a teacher during confinement? \\
Can you describe your 'before' and 'after'? \\
\hline Describe, briefly, which actions you have carried out and which technologies you have used. \\
\hline What content do you think you need specific training on? Please answer briefly. \\
Source: Own elaboration.
\end{tabular}
Source: Own elaboration.

Open-ended questions were included at the end of the questionnaire in order to obtain more information regarding the current situation caused by COVID-19, which has led to the need to transition from face-to-face teaching to virtual teaching. These questions helped us to understand the feelings and thoughts of teachers better.

The questionnaires were distributed to teachers in several ways. Firstly, the questionnaire was sent to the headteachers of schools, as well as to the heads of studies at secondary schools, so that they could disseminate it among their teaching staff; this was reinforced by us sending it to fellow teachers, so that they would circulate it among their colleagues. It was also disseminated via social networks such as Facebook and Twitter. Questionnaires were distributed between 20 and 30 May 2020.

This questionnaire was implemented using the 'Google Forms' tool, because the received responses can be monitored in real-time and because it is also possible to download them in .xls format, which allows for better processing and avoids coding errors.

Once the data had been collected and downloaded, they were analyzed using the SPSS software (IBM Corp. SPSS statistics, v. 24, Armonk, NY, USA), which carried out a descriptive analysis of the data obtained in the study. The level of digital teaching competence analyzed in the study establishes levels of competence similar to those established in the Common European Framework of References for Languages (CEFR), based on the percentages previously assigned by the reference study [25] (see Table 3).

Table 3. Initial and final values to determine the level of digital teaching competence.

\begin{tabular}{ccc}
\hline Level & Initial Value & Final Value \\
\hline A0 & $0.00 \%$ & $14.27 \%$ \\
\hline A1 & $14.28 \%$ & $28.56 \%$ \\
\hline A2 & $28.56 \%$ & $42.85 \%$ \\
\hline B1 & $42.85 \%$ & $57.12 \%$ \\
\hline B2 & $57.12 \%$ & $71.40 \%$ \\
\hline C1 & $71.40 \%$ & $85.68 \%$ \\
\hline C2 & $85.68 \%$ & $100.00 \%$ \\
\hline
\end{tabular}

Source: Own elaboration.

This assessment is based on the questionnaire by Tourón et al. [25], and validated and based on the competences set out by INTEF in the common framework of digital competence for teachers, with the aim of discovering what is the current state of digital teaching competence.

The percentages referred to in Table 3 are the result of converting the direct scores of the Likert scale into percentages, as used in the reference article [25], without weighting between the different items.

Once the results are obtained, we can assess the self-perception of teachers' digital teaching competence in order to discover their results in aggregate or individually. 


\section{Results}

Data collection resulted in 208 responses, of which 31 came from foreign countries and were thus discarded. Of the valid responses (177), 65 were from men and 112 from women. In terms of age, the mean age of the group was 45 (with a standard deviation of 8.36).

Regarding teaching experience, a wide range of experience (in years) has been observed, although the majority of the teachers who completed the questionnaire had an average of 14.9 years of teaching experience.

A global analysis of the results on knowledge and use of digital competence items is presented in Table 4 (the color coding is a visual aid that aims to detect low values of the level of digital competence).

Table 4. Overall results for each of the items.

\begin{tabular}{|c|c|c|c|c|c|c|c|c|c|c|c|c|}
\hline \multirow{2}{*}{ Item Number } & \multicolumn{6}{|c|}{ Knowledge } & \multicolumn{6}{|c|}{ Use } \\
\hline & Men & Level & Women & Level & Total & Level & Men & Level & Women & Level & Total & Level \\
\hline Item 1 & $81.20 \%$ & $\mathrm{C} 1$ & $77.38 \%$ & $\mathrm{C} 1$ & $78.78 \%$ & $\mathrm{C} 1$ & $77.26 \%$ & $\mathrm{C} 1$ & $76.62 \%$ & $\mathrm{C} 1$ & $76.85 \%$ & $\mathrm{C} 1$ \\
\hline Item 2 & $61.34 \%$ & B2 & $63.91 \%$ & B2 & $62.95 \%$ & B2 & $54.83 \%$ & B1 & $57.40 \%$ & B2 & $56.42 \%$ & B1 \\
\hline Item 3 & $70.82 \%$ & B2 & $67.94 \%$ & B2 & $69.00 \%$ & B2 & $64.19 \%$ & B2 & $62.83 \%$ & B2 & $63.33 \%$ & B2 \\
\hline Item 4 & $86.67 \%$ & $\mathrm{C} 2$ & $83.44 \%$ & $\mathrm{C} 1$ & $84.61 \%$ & $\mathrm{C} 1$ & $82.10 \%$ & $\mathrm{C} 1$ & $82.25 \%$ & $\mathrm{C} 1$ & $82.19 \%$ & $\mathrm{C} 1$ \\
\hline Item 5 & $80.26 \%$ & C1 & $69.90 \%$ & B2 & $73.71 \%$ & C1 & $76.50 \%$ & C1 & $67.33 \%$ & B2 & $70.73 \%$ & B2 \\
\hline Item 6 & $69.14 \%$ & B2 & $63.15 \%$ & B2 & $65.39 \%$ & B2 & $62.22 \%$ & B2 & $58.50 \%$ & B2 & $59.90 \%$ & B2 \\
\hline Item 7 & $66.33 \%$ & B2 & $66.46 \%$ & B2 & $66.41 \%$ & B2 & $51.02 \%$ & B1 & $59.02 \%$ & B2 & $55.98 \%$ & B1 \\
\hline Item 8 & $83.59 \%$ & $\mathrm{C} 1$ & $82.06 \%$ & C1 & $82.62 \%$ & C1 & $79.73 \%$ & $\mathrm{C} 1$ & $79.01 \%$ & $\mathrm{C} 1$ & $79.27 \%$ & $\mathrm{C} 1$ \\
\hline Item 9 & $77.14 \%$ & $\mathrm{C} 1$ & $69.16 \%$ & B2 & $72.14 \%$ & C1 & $72.38 \%$ & C1 & $66.44 \%$ & B2 & $68.66 \%$ & B2 \\
\hline Item 10 & $86.84 \%$ & $\mathrm{C} 2$ & $83.44 \%$ & $\mathrm{C} 1$ & $84.68 \%$ & $\mathrm{C} 1$ & $82.89 \%$ & $\mathrm{C} 1$ & $81.35 \%$ & $\mathrm{C} 1$ & $81.92 \%$ & $\mathrm{C} 1$ \\
\hline Item 11 & $88.16 \%$ & $\mathrm{C} 2$ & $82.36 \%$ & C1 & $84.48 \%$ & C1 & $84.21 \%$ & C1 & $81.39 \%$ & $\mathrm{C} 1$ & $82.42 \%$ & C1 \\
\hline Item 12 & $70.46 \%$ & B2 & $63.31 \%$ & B2 & $65.97 \%$ & B2 & $52.05 \%$ & B1 & $52.00 \%$ & B1 & $52.02 \%$ & B1 \\
\hline Item 13 & $72.20 \%$ & $\mathrm{C} 1$ & $59.89 \%$ & B2 & $64.47 \%$ & B2 & $61.58 \%$ & B2 & $56.91 \%$ & B1 & $58.67 \%$ & B2 \\
\hline Item 14 & $62.67 \%$ & B2 & $60.69 \%$ & B2 & $61.41 \%$ & B2 & $53.33 \%$ & B1 & $57.03 \%$ & B1 & $55.67 \%$ & B1 \\
\hline Item 15 & $73.84 \%$ & C1 & $72.00 \%$ & $\mathrm{C} 1$ & $72.67 \%$ & $\mathrm{C} 1$ & $69.42 \%$ & B2 & $71.31 \%$ & B2 & $70.61 \%$ & B2 \\
\hline Item 16 & $86.48 \%$ & $\mathrm{C} 2$ & $78.68 \%$ & C1 & $81.50 \%$ & $\mathrm{C} 1$ & $79.81 \%$ & $\mathrm{C} 1$ & $76.92 \%$ & $\mathrm{C} 1$ & $77.98 \%$ & C1 \\
\hline Item 17 & $87.22 \%$ & $\mathrm{C} 2$ & $81.28 \%$ & $\mathrm{C} 1$ & $83.45 \%$ & $\mathrm{C} 1$ & $74.10 \%$ & C1 & $74.59 \%$ & C1 & $74.41 \%$ & $\mathrm{C} 1$ \\
\hline Item 18 & $80.00 \%$ & $\mathrm{C} 1$ & $69.42 \%$ & B2 & $73.33 \%$ & $\mathrm{C} 1$ & $69.90 \%$ & B2 & $68.39 \%$ & B2 & $68.95 \%$ & B2 \\
\hline Item 19 & $51.71 \%$ & B1 & $42.86 \%$ & B1 & $46.33 \%$ & B1 & $33.26 \%$ & $\mathrm{~A} 2$ & $34.69 \%$ & $\mathrm{~A} 2$ & $34.14 \%$ & $\mathrm{~A} 2$ \\
\hline Item 20 & $67.26 \%$ & B2 & $57.26 \%$ & B2 & $61.01 \%$ & B2 & $54.37 \%$ & B1 & $53.54 \%$ & B1 & $53.85 \%$ & B1 \\
\hline Item 21 & $80.00 \%$ & $\mathrm{C} 1$ & $70.09 \%$ & B2 & $73.75 \%$ & $\mathrm{C} 1$ & $71.81 \%$ & $\mathrm{C} 1$ & $65.31 \%$ & B2 & $67.73 \%$ & B2 \\
\hline Item 22 & $75.81 \%$ & $\mathrm{C} 1$ & $69.26 \%$ & B2 & $71.71 \%$ & $\mathrm{C} 1$ & $65.90 \%$ & B2 & $61.79 \%$ & B2 & $63.35 \%$ & B2 \\
\hline Item 23 & $59.49 \%$ & B2 & $54.69 \%$ & B1 & $56.56 \%$ & B1 & $52.10 \%$ & B1 & $50.35 \%$ & B1 & $51.06 \%$ & B1 \\
\hline Item 24 & $82.82 \%$ & $\mathrm{C} 1$ & $72.21 \%$ & $\mathrm{C} 1$ & $76.10 \%$ & $\mathrm{C} 1$ & $80.31 \%$ & $\mathrm{C} 1$ & $71.21 \%$ & B2 & $74.54 \%$ & $\mathrm{C} 1$ \\
\hline Item 25 & $80.64 \%$ & $\mathrm{C} 1$ & $70.99 \%$ & B2 & $74.53 \%$ & $\mathrm{C} 1$ & $75.56 \%$ & C1 & $67.83 \%$ & B2 & $70.67 \%$ & B2 \\
\hline Item 26 & $79.43 \%$ & $\mathrm{C} 1$ & $63.02 \%$ & B2 & $69.20 \%$ & B2 & $76.00 \%$ & C1 & $59.25 \%$ & B2 & $65.63 \%$ & B2 \\
\hline Item 27 & $73.87 \%$ & $\mathrm{C} 1$ & $59.76 \%$ & B2 & $65.23 \%$ & B2 & $68.42 \%$ & B2 & $57.38 \%$ & B2 & $61.71 \%$ & B2 \\
\hline Item 28 & $70.62 \%$ & B2 & $59.40 \%$ & B2 & $63.71 \%$ & B2 & $52.92 \%$ & B1 & $50.58 \%$ & B1 & $51.49 \%$ & B1 \\
\hline Item 29 & $76.38 \%$ & C1 & $61.14 \%$ & B2 & $66.86 \%$ & B2 & $72.76 \%$ & C1 & $61.28 \%$ & B2 & $65.67 \%$ & B2 \\
\hline Item 30 & $74.62 \%$ & $\mathrm{C} 1$ & $69.73 \%$ & B2 & $71.57 \%$ & $\mathrm{C} 1$ & $65.79 \%$ & B2 & $65.37 \%$ & B2 & $65.53 \%$ & B2 \\
\hline Item 31 & $79.15 \%$ & $\mathrm{C} 1$ & $68.70 \%$ & B2 & $72.47 \%$ & $\mathrm{C} 1$ & $71.62 \%$ & C1 & $65.71 \%$ & B2 & $67.86 \%$ & B2 \\
\hline Item 32 & $75.73 \%$ & $\mathrm{C} 1$ & $71.21 \%$ & B2 & $72.84 \%$ & $\mathrm{C} 1$ & $69.28 \%$ & B2 & $68.86 \%$ & B2 & $69.01 \%$ & B2 \\
\hline Item 33 & $72.37 \%$ & $\mathrm{C} 1$ & $66.11 \%$ & $\mathrm{~B} 2$ & $68.43 \%$ & B2 & $65.60 \%$ & B2 & $63.17 \%$ & B2 & $64.08 \%$ & B2 \\
\hline Item 34 & $68.45 \%$ & B2 & $57.52 \%$ & B2 & $61.73 \%$ & B2 & $59.52 \%$ & B2 & $55.01 \%$ & B1 & $56.76 \%$ & B1 \\
\hline Item 35 & $76.76 \%$ & C1 & $69.29 \%$ & B2 & $72.07 \%$ & C1 & $64.38 \%$ & B2 & $64.76 \%$ & B2 & $64.62 \%$ & B2 \\
\hline Item 36 & $57.34 \%$ & B2 & $48.57 \%$ & B1 & $52.04 \%$ & B1 & $49.59 \%$ & B1 & $44.73 \%$ & B1 & $46.65 \%$ & B1 \\
\hline Item 37 & $71.62 \%$ & $\mathrm{C} 1$ & $69.39 \%$ & B2 & $70.22 \%$ & B2 & $65.52 \%$ & B2 & $64.51 \%$ & B2 & $64.89 \%$ & B2 \\
\hline Item 38 & $63.10 \%$ & B2 & $48.79 \%$ & B1 & $54.57 \%$ & B1 & $56.75 \%$ & B1 & $44.64 \%$ & B1 & $49.59 \%$ & B1 \\
\hline Item 39 & $72.82 \%$ & $\mathrm{C} 1$ & $60.74 \%$ & B2 & $65.30 \%$ & B2 & $68.45 \%$ & B2 & $59.61 \%$ & B2 & $62.99 \%$ & B2 \\
\hline Item 40 & $76.00 \%$ & $\mathrm{C} 1$ & $67.69 \%$ & B2 & $70.79 \%$ & B2 & $69.14 \%$ & B2 & $63.95 \%$ & B2 & $65.88 \%$ & B2 \\
\hline Item 41 & $80.08 \%$ & $\mathrm{C} 1$ & $67.52 \%$ & B2 & $72.20 \%$ & $\mathrm{C} 1$ & $78.20 \%$ & C1 & $65.40 \%$ & B2 & $70.17 \%$ & B2 \\
\hline Item 42 & $79.24 \%$ & $\mathrm{C} 1$ & $70.88 \%$ & B2 & $73.94 \%$ & $\mathrm{C} 1$ & $74.10 \%$ & $\mathrm{C} 1$ & $69.66 \%$ & B2 & $71.29 \%$ & B2 \\
\hline Item 43 & $60.61 \%$ & B2 & $54.99 \%$ & B1 & $57.06 \%$ & B1 & $51.81 \%$ & B1 & $52.21 \%$ & B1 & $52.06 \%$ & B1 \\
\hline Item 44 & $67.71 \%$ & B2 & $60.44 \%$ & B2 & $63.23 \%$ & B2 & $63.01 \%$ & B2 & $58.15 \%$ & B2 & $60.05 \%$ & B2 \\
\hline Item 45 & $68.91 \%$ & B2 & $64.59 \%$ & B2 & $66.16 \%$ & B2 & $63.66 \%$ & B2 & $61.29 \%$ & B2 & $62.16 \%$ & B2 \\
\hline Item 46 & $72.82 \%$ & C1 & $62.46 \%$ & B2 & $66.32 \%$ & B2 & $66.27 \%$ & B2 & $60.50 \%$ & B2 & $62.68 \%$ & B2 \\
\hline Item 47 & $64.48 \%$ & B2 & $62.72 \%$ & B2 & $63.38 \%$ & B2 & $55.98 \%$ & B1 & $57.98 \%$ & B2 & $57.22 \%$ & B2 \\
\hline Item 48 & $59.68 \%$ & B2 & $58.02 \%$ & B2 & $58.66 \%$ & B2 & $50.34 \%$ & B1 & $54.79 \%$ & B1 & $53.04 \%$ & B1 \\
\hline Item 49 & $65.42 \%$ & B2 & $57.14 \%$ & B2 & $60.52 \%$ & B2 & $51.89 \%$ & B1 & $48.48 \%$ & B1 & $49.87 \%$ & B1 \\
\hline Item 50 & $73.90 \%$ & C1 & $66.39 \%$ & B2 & $69.25 \%$ & B2 & $63.62 \%$ & B2 & $60.60 \%$ & B2 & $61.76 \%$ & B2 \\
\hline Item 51 & $62.11 \%$ & B2 & $61.62 \%$ & B2 & $61.80 \%$ & B2 & $50.21 \%$ & B1 & $54.49 \%$ & B1 & $52.88 \%$ & B1 \\
\hline Item 52 & $78.38 \%$ & C1 & $71.32 \%$ & B2 & $73.96 \%$ & $\mathrm{C} 1$ & $73.12 \%$ & $\mathrm{C} 1$ & $69.05 \%$ & B2 & $70.58 \%$ & B2 \\
\hline Item 53 & $71.43 \%$ & $\mathrm{C} 1$ & $63.48 \%$ & B2 & $66.42 \%$ & B2 & $67.51 \%$ & B2 & $62.83 \%$ & B2 & $64.58 \%$ & B2 \\
\hline Item 54 & $85.52 \%$ & $\mathrm{C} 1$ & $75.90 \%$ & $\mathrm{C} 1$ & $79.40 \%$ & $\mathrm{C} 1$ & $81.71 \%$ & $\mathrm{C} 1$ & $74.62 \%$ & $\mathrm{C} 1$ & $77.21 \%$ & $\mathrm{C} 1$ \\
\hline Total & $73.35 \%$ & $\mathrm{C} 1$ & $66.12 \%$ & B2 & $68.83 \%$ & B2 & $65.70 \%$ & B2 & $62.46 \%$ & B2 & $63.69 \%$ & B2 \\
\hline
\end{tabular}

The data presented in Table 4 show, as expected, that the knowledge of items is higher than their use in all cases except for one; in this case, the use of the item is higher than its knowledge, which shows that the results make sense in terms of the responses collected. It is evident that the most well-known items are used more frequently, with respondents reporting over $84 \%$ in the knowledge of, and over $80 \%$ in the use of, items 4 (solutions for management and storage in the 'cloud', file sharing, granting access privileges, etc.), 10 (tools for online communication: forums, instant messaging, chats, videoconferences, etc.), and 11 (tools for storage and management of shared files and content, e.g., Drive, Box, Dropbox, Office 365, etc.). 
On the other hand, item 19 (augmented reality-based content tools) has by far the lowest values, while item 36 (tools for recovering deleted, damaged, or inaccessible files, files with formatting errors, etc.) also has low values.

Regarding the knowledge of items (Figure 1), of the 54 items studied, 23 items are rated $\mathrm{C} 1,26$ items $\mathrm{B} 2$, and 5 items $\mathrm{A} 2$. In terms of the use of items, of the 54 items studied, 8 items are rated $\mathrm{C} 1,31$ items $\mathrm{B} 2,13$ items $\mathrm{B} 1$, and only 1 item is rated as $\mathrm{A} 2$.

\section{KNOWLEDGE}

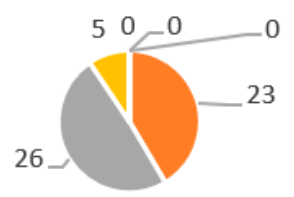

$-\mathrm{C} 2=\mathrm{C} 1=\mathrm{B} 2=\mathrm{B} 1=\mathrm{A} 2-\mathrm{A} 1$

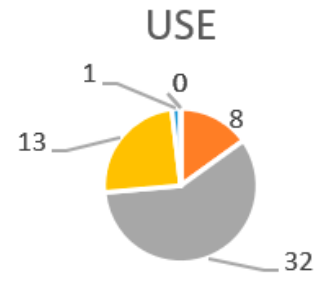

- 2 2 $-\mathrm{C} 1=\mathrm{B} 2=\mathrm{B} 1=\mathrm{A} 2=\mathrm{A} 1$

Figure 1. Overall rating of items in knowledge and use. Source: Own elaboration.

If we separate by gender, we can see the score levels achieved by men and women in Table 5, both in knowledge and use of the items outlined in the questionnaire.

Table 5. Item ratings by gender.

\begin{tabular}{ccccc}
\hline \multirow{2}{*}{ Levels } & \multicolumn{2}{c}{ Knowledge } & \multicolumn{2}{c}{ Use } \\
\cline { 2 - 5 } & Men & Women & Men & Women \\
\hline C2 & 5 & 0 & 0 & 0 \\
\hline C1 & 29 & 98 & 20 & 7 \\
\hline B2 & 19 & 5 & 13 & 31 \\
\hline B1 & 1 & 0 & 1 & 13 \\
\hline A2 & 0 & 0 & 0 & 0 \\
\hline A1 & 0 & & &
\end{tabular}

Source: Own elaboration.

In the knowledge of items, men achieve the highest score in 5 items, while women do not achieve the highest score in any item. In the use of items, neither men nor women achieve the highest level.

A Cl level of knowledge is achieved by men in 29 items and by women in only 9 items. A C1 level of use is achieved by men in 18 items and by women in 7 items.

A B2 level of knowledge is achieved by men in 19 items and by women in 38 items. Men achieve a B2 level of use in 20 items, while women achieve this level in 31 items.

$\mathrm{A} \mathrm{Bl}$ level of knowledge is achieved by men in one item and by women in seven items. Both men and women achieve a B1 level of use in 15 items.

With respect to the A2 level, no items are classified at this level in terms of knowledge; but with respect to the level of use, each gender achieved this level in one item.

\subsection{Results in Terms of Areas with Aggregated Indices}

Within the theoretical framework, digital competence can be grouped into several areas, by aggregating each item as belonging to a certain area.

\subsubsection{Information Area}

In order to calculate the digital competence in the area of information, eight items are considered from the theoretical framework of this study, which are the knowledge and use of identifying, locating, retrieving, storing, organizing, and analyzing digital information, and judging its relevance and purpose. 
The results obtained for these items are presented in Table 6 .

Table 6. Values of items in the area of information.

\begin{tabular}{ccccccc}
\hline \multirow{2}{*}{$\begin{array}{c}\text { Item Number for Area } \\
\text { of Information }\end{array}$} & \multicolumn{3}{c}{ Knowledge } & \multicolumn{3}{c}{ Use } \\
\cline { 2 - 7 } & Men & Women & Total & Men & Women & Total \\
\hline Item 1 & $81.20 \%$ & $77.38 \%$ & $78.78 \%$ & $77.26 \%$ & $76.62 \%$ & $76.85 \%$ \\
\hline Item 6 & $69.14 \%$ & $63.15 \%$ & $65.39 \%$ & $62.22 \%$ & $58.50 \%$ & $59.90 \%$ \\
\hline Item 11 & $88.16 \%$ & $82.36 \%$ & $84.48 \%$ & $84.21 \%$ & $81.39 \%$ & $82.42 \%$ \\
\hline Item 18 & $80.00 \%$ & $69.42 \%$ & $73.33 \%$ & $69.90 \%$ & $68.39 \%$ & $68.95 \%$ \\
\hline Item 22 & $67.26 \%$ & $57.26 \%$ & $61.01 \%$ & $54.37 \%$ & $53.54 \%$ & $53.85 \%$ \\
\hline Item 24 & $82.82 \%$ & $72.21 \%$ & $76.10 \%$ & $80.31 \%$ & $71.21 \%$ & $74.54 \%$ \\
\hline Item 36 & $57.34 \%$ & $48.57 \%$ & $52.04 \%$ & $49.59 \%$ & $44.73 \%$ & $46.65 \%$ \\
\hline Item 44 & $67.71 \%$ & $60.44 \%$ & $63.23 \%$ & $63.01 \%$ & $58.15 \%$ & $60.05 \%$ \\
\hline Total & $74.20 \%$ & $66.35 \%$ & $69.29 \%$ & $67.61 \%$ & $64.07 \%$ & $65.40 \%$ \\
\hline $\begin{array}{c}\text { Level for Total } \\
\text { percentage }\end{array}$ & $\mathrm{C} 1$ & $\mathrm{~B} 2$ & $\mathrm{~B} 2$ & $\mathrm{~B} 2$ & $\mathrm{~B} \%$ & $\mathrm{~B} 2$ \\
\end{tabular}

Source: Own elaboration.

The overall level achieved by the respondents is a B2 or 'upper intermediate' level, both in use and knowledge of items in the area of information.

When separated by gender, the results show that men achieve an 'advanced' $\mathrm{C} 1$ level of knowledge, although not the maximum, while women remain at the B2 or 'upper intermediate' level. As a whole, the aggregate of teaching staff achieves an 'upper intermediate' level. Regarding the use of items in the area of information, there are fewer differences between men and women, and although an 'upper intermediate' level is achieved, its score is somewhat lower.

\subsubsection{Communication Area}

In order to calculate digital competence in the area of communication, nine items are considered from the theoretical framework of this study. The results obtained for these items are presented in Table 7.

Table 7. Values of items in the area of communication.

\begin{tabular}{|c|c|c|c|c|c|c|}
\hline \multirow{2}{*}{$\begin{array}{l}\text { Item Number for Area } \\
\text { of Communication }\end{array}$} & \multicolumn{3}{|c|}{ Knowledge } & \multicolumn{3}{|c|}{ Use } \\
\hline & Men & Women & Total & Men & Women & Total \\
\hline Item 3 & $70.82 \%$ & $67.94 \%$ & $69.00 \%$ & $64.19 \%$ & $62.83 \%$ & $63.33 \%$ \\
\hline Item 8 & $83.59 \%$ & $82.06 \%$ & $82.62 \%$ & $79.73 \%$ & $79.01 \%$ & $79.27 \%$ \\
\hline Item 10 & $86.84 \%$ & $83.44 \%$ & $84.68 \%$ & $82.89 \%$ & $81.35 \%$ & $81.92 \%$ \\
\hline Item 15 & $73.84 \%$ & $72.00 \%$ & $72.67 \%$ & $69.42 \%$ & $71.31 \%$ & $70.61 \%$ \\
\hline Item 17 & $87.22 \%$ & $81.28 \%$ & $83.45 \%$ & $74.10 \%$ & $74.59 \%$ & $74.41 \%$ \\
\hline Item 23 & $59.49 \%$ & $54.69 \%$ & $56.56 \%$ & $52.10 \%$ & $50.35 \%$ & $51.06 \%$ \\
\hline Item 33 & $72.37 \%$ & $66.11 \%$ & $68.43 \%$ & $65.60 \%$ & $63.17 \%$ & $64.08 \%$ \\
\hline Item 35 & $76.76 \%$ & $69.29 \%$ & $72.07 \%$ & $64.38 \%$ & $64.76 \%$ & $64.62 \%$ \\
\hline Item 54 & $85.52 \%$ & $75.90 \%$ & $79.40 \%$ & $81.71 \%$ & $74.62 \%$ & $77.21 \%$ \\
\hline Total & $77.38 \%$ & $72.53 \%$ & $74.32 \%$ & $70.46 \%$ & $69.11 \%$ & $69.61 \%$ \\
\hline $\begin{array}{l}\text { Level for Total } \\
\text { percentage }\end{array}$ & $\mathrm{C} 1$ & $\mathrm{C} 1$ & $\mathrm{C} 1$ & B2 & B2 & B2 \\
\hline
\end{tabular}

Source: Own elaboration.

Overall, the respondents achieve a C1 or 'advanced' level of knowledge, but only a B2 or 'upper intermediate' level of use.

When separated by gender, both men and women achieve a $\mathrm{Cl}$ 'advanced' level.

As a whole, the aggregate of teaching staff achieves a B2 level of use, with minimal differences between men and women; and although an 'upper intermediate' level is achieved, the score for the level of use is somewhat lower than that of knowledge. 


\subsubsection{Content Creation Area}

The area of content creation analyzes the knowledge and use of creating and editing new content (from word processing to images and video), integrating and re-elaborating previous knowledge and content, producing creative expressions, media products and programming, and addressing and enforcing the rights of intellectual property licenses.

In order to calculate digital competence in the area of content creation, 16 items are considered from the theoretical framework of this study.

The results obtained from these items are presented in Table 8.

Table 8. Values of items in the area of content creation.

\begin{tabular}{|c|c|c|c|c|c|c|}
\hline \multirow{2}{*}{$\begin{array}{l}\text { Item Number for Area } \\
\text { of Content Creation }\end{array}$} & \multicolumn{3}{|c|}{ Knowledge } & \multicolumn{3}{|c|}{ Use } \\
\hline & Men & Women & Total & Men & Women & Total \\
\hline Item 2 & $61.34 \%$ & $63.91 \%$ & $62.95 \%$ & $54.83 \%$ & $57.40 \%$ & $56.42 \%$ \\
\hline Item 7 & $66.33 \%$ & $66.46 \%$ & $66.41 \%$ & $51.02 \%$ & $59.02 \%$ & $55.98 \%$ \\
\hline Item 12 & $70.46 \%$ & $63.31 \%$ & $65.97 \%$ & $52.05 \%$ & $52.00 \%$ & $52.02 \%$ \\
\hline Item 16 & $86.48 \%$ & $78.68 \%$ & $81.50 \%$ & $79.81 \%$ & $76.92 \%$ & $77.98 \%$ \\
\hline Item 19 & $51.71 \%$ & $42.86 \%$ & $46.33 \%$ & $33.26 \%$ & $34.69 \%$ & $34.14 \%$ \\
\hline Item 22 & $75.81 \%$ & $69.26 \%$ & $71.71 \%$ & $65.90 \%$ & $61.79 \%$ & $63.35 \%$ \\
\hline Item 28 & $70.62 \%$ & $59.40 \%$ & $63.71 \%$ & $52.92 \%$ & $50.58 \%$ & $51.49 \%$ \\
\hline Item 30 & $74.62 \%$ & $69.73 \%$ & $71.57 \%$ & $65.79 \%$ & $65.37 \%$ & $65.53 \%$ \\
\hline Item 34 & $68.45 \%$ & $57.52 \%$ & $61.73 \%$ & $59.52 \%$ & $55.01 \%$ & $56.76 \%$ \\
\hline Item 37 & $71.62 \%$ & $69.39 \%$ & $70.22 \%$ & $65.52 \%$ & $64.51 \%$ & $64.89 \%$ \\
\hline Item 38 & $63.10 \%$ & $48.79 \%$ & $54.57 \%$ & $56.75 \%$ & $44.64 \%$ & $49.59 \%$ \\
\hline Item 47 & $64.48 \%$ & $62.72 \%$ & $63.38 \%$ & $55.98 \%$ & $57.98 \%$ & $57.22 \%$ \\
\hline Item 49 & $65.42 \%$ & $57.14 \%$ & $60.52 \%$ & $51.89 \%$ & $48.48 \%$ & $49.87 \%$ \\
\hline Item 50 & $73.90 \%$ & $66.39 \%$ & $69.25 \%$ & $63.62 \%$ & $60.60 \%$ & $61.76 \%$ \\
\hline Item 51 & $62.11 \%$ & $61.62 \%$ & $61.80 \%$ & $50.21 \%$ & $54.49 \%$ & $52.88 \%$ \\
\hline Item 52 & $78.38 \%$ & $71.32 \%$ & $73.96 \%$ & $73.12 \%$ & $69.05 \%$ & $70.58 \%$ \\
\hline Total & $69.05 \%$ & $63.03 \%$ & $65.35 \%$ & $58.26 \%$ & $57.03 \%$ & $57.53 \%$ \\
\hline $\begin{array}{l}\text { Level for Total } \\
\text { percentage }\end{array}$ & B2 & $\mathrm{B} 2$ & $\mathrm{~B} 2$ & $\mathrm{~B} 2$ & B1 & $\mathrm{B} 2$ \\
\hline
\end{tabular}

Source: Own elaboration.

In general, the respondents achieve a B2 or 'upper intermediate' level of knowledge, and likewise a B2 or 'upper intermediate' level of use.

Separated by gender, both men and women achieve a B2 or 'upper intermediate' level of knowledge.

As a whole, the aggregate of teaching staff achieves a B2 level of use, with minimal differences between men and women; and although men achieve an 'upper intermediate' level and women achieve a 'lower intermediate' level, the difference is almost negligible $(1.23 \%)$, and is due to the jump in the scale.

As usual, the use of items is lower than their knowledge, and in this case (content creation area), by $7.82 \%$.

\subsubsection{Security Area}

The security area analyzes personal protection, data protection, digital identity protection, security measures, and safe and sustainable use.

In order to calculate digital competence in the area of security, nine items are considered from the theoretical framework of this study.

The results obtained are presented in Table 9, which shows the items differentiated by knowledge and use, as well as by the gender of the teachers surveyed. 
Table 9. Values of items in the area of security.

\begin{tabular}{ccccccc}
\hline \multirow{2}{*}{$\begin{array}{c}\text { Item Number for } \\
\text { Area of Security }\end{array}$} & \multicolumn{3}{c}{ Knowledge } & \multicolumn{3}{c}{ Use } \\
\cline { 2 - 7 } & Men & Women & Total & Men & Women & Total \\
\hline Item 5 & $80.26 \%$ & $69.90 \%$ & $73.71 \%$ & $76.50 \%$ & $67.33 \%$ & $70.73 \%$ \\
\hline Item 13 & $72.20 \%$ & $59.89 \%$ & $64.47 \%$ & $61.58 \%$ & $56.91 \%$ & $58.67 \%$ \\
\hline Item 27 & $73.87 \%$ & $59.76 \%$ & $65.23 \%$ & $68.42 \%$ & $57.38 \%$ & $61.71 \%$ \\
\hline Item 29 & $76.38 \%$ & $61.14 \%$ & $66.86 \%$ & $72.76 \%$ & $61.28 \%$ & $65.67 \%$ \\
\hline Item 32 & $75.73 \%$ & $71.21 \%$ & $72.84 \%$ & $69.28 \%$ & $68.86 \%$ & $69.01 \%$ \\
\hline Item 39 & $72.82 \%$ & $60.74 \%$ & $65.30 \%$ & $68.45 \%$ & $59.61 \%$ & $62.99 \%$ \\
\hline Item 43 & $60.61 \%$ & $54.99 \%$ & $57.06 \%$ & $51.81 \%$ & $52.21 \%$ & $52.06 \%$ \\
\hline Item 46 & $72.82 \%$ & $62.46 \%$ & $66.32 \%$ & $66.27 \%$ & $60.50 \%$ & $62.68 \%$ \\
\hline Item 53 & $71.43 \%$ & $63.48 \%$ & $66.42 \%$ & $67.51 \%$ & $62.83 \%$ & $64.58 \%$ \\
\hline Total & $72.90 \%$ & $62.62 \%$ & $66.47 \%$ & $66.95 \%$ & $60.77 \%$ & $63.12 \%$ \\
\hline $\begin{array}{c}\text { Level for Total } \\
\text { percentage }\end{array}$ & $\mathrm{C} 1$ & $\mathrm{~B} 2$ & $\mathrm{~B} 2$ & \multirow{2}{*}{$\mathrm{B} 2$} & $\mathrm{~B} 2$ & $\mathrm{~B} 2$ \\
\hline \begin{tabular}{c} 
Source: Own elaboration. \\
\hline
\end{tabular} & & & & & \\
\hline
\end{tabular}

Overall, the respondents achieve a B2 or 'upper intermediate' level of knowledge, and a B2 or 'upper intermediate' level of use.

Separated by gender, men achieve an 'advanced' $\mathrm{Cl}$ level of knowledge, and women achieve a B2 or 'upper intermediate' level of knowledge.

As a whole, the aggregate of teaching staff achieves a B2 level of use; although there is a difference of $6.18 \%$ between men and women, an 'upper intermediate' level is achieved by both genders.

As usual, the use of items is lower than their knowledge, and in this case (security area), by $3.35 \%$.

\subsubsection{Problem-Solving Area}

The problem-solving area analyzes the knowledge and use of identifying needs and digital resources, making informed decisions about the most appropriate digital tools according to purpose or need, solving conceptual problems by digital means, using technologies creatively, solving technical problems, and updating one's own and others' competence.

In order to calculate digital competence in the area of problem-solving, 12 items were considered from the theoretical framework of this study.

The results obtained are presented in Table 10.

Table 10. Values of items in the problem-solving area.

\begin{tabular}{|c|c|c|c|c|c|c|}
\hline \multirow{2}{*}{$\begin{array}{l}\text { Item Number for } \\
\text { Problem-Solving Area }\end{array}$} & \multicolumn{3}{|c|}{ Knowledge } & \multicolumn{3}{|c|}{ Use } \\
\hline & Men & Women & Total & Men & Women & Total \\
\hline item 4 & $86.67 \%$ & $83.44 \%$ & $84.61 \%$ & $82.10 \%$ & $82.25 \%$ & $82.19 \%$ \\
\hline item 9 & $77.14 \%$ & $69.16 \%$ & $72.14 \%$ & $72.38 \%$ & $66.44 \%$ & $68.66 \%$ \\
\hline item 14 & $62.67 \%$ & $60.69 \%$ & $61.41 \%$ & $53.33 \%$ & $57.03 \%$ & $55.67 \%$ \\
\hline item 21 & $80.00 \%$ & $70.09 \%$ & $73.75 \%$ & $71.81 \%$ & $65.31 \%$ & $67.73 \%$ \\
\hline item 25 & $80.64 \%$ & $70.99 \%$ & $74.53 \%$ & $75.56 \%$ & $67.83 \%$ & $70.67 \%$ \\
\hline item 26 & $79.43 \%$ & $63.02 \%$ & $69.20 \%$ & $76.00 \%$ & $59.25 \%$ & $65.63 \%$ \\
\hline item 31 & $79.15 \%$ & $68.70 \%$ & $72.47 \%$ & $71.62 \%$ & $65.71 \%$ & $67.86 \%$ \\
\hline item 40 & $76.00 \%$ & $67.69 \%$ & $70.79 \%$ & $69.14 \%$ & $63.95 \%$ & $65.88 \%$ \\
\hline item 41 & $80.08 \%$ & $67.52 \%$ & $72.20 \%$ & $78.20 \%$ & $65.40 \%$ & $70.17 \%$ \\
\hline item 42 & $79.24 \%$ & $70.88 \%$ & $73.94 \%$ & $74.10 \%$ & $69.66 \%$ & $71.29 \%$ \\
\hline item 45 & $68.91 \%$ & $64.59 \%$ & $66.16 \%$ & $63.66 \%$ & $61.29 \%$ & $62.16 \%$ \\
\hline item 48 & $59.68 \%$ & $58.02 \%$ & $58.66 \%$ & $50.34 \%$ & $54.79 \%$ & $53.04 \%$ \\
\hline Total & $75.80 \%$ & $67.90 \%$ & $70.82 \%$ & $69.85 \%$ & $64.91 \%$ & $66.75 \%$ \\
\hline $\begin{array}{l}\text { Level for Total } \\
\text { percentage }\end{array}$ & $\mathrm{C} 1$ & B2 & B2 & B2 & B2 & B2 \\
\hline
\end{tabular}


In general, respondents achieve a B2 or 'upper intermediate' level of knowledge and a B2 or 'upper intermediate' level of use.

Separated by gender, men achieve an 'advanced' C1 level of knowledge, and women achieve a B2 or 'upper intermediate' level, with a difference of $7.9 \%$.

As a whole, the aggregate of teaching staff achieves a B2 level of use; although there is a difference of $4.94 \%$ between men and women, an 'upper intermediate' level is achieved by both.

\subsection{Overall Results}

In this section, we will discuss the results achieved when taking all items into consideration.

As shown in Table 11, there is a difference of $5.14 \%$ between the knowledge and use of the items reported by teachers. In any case, both men and women achieve a B2 'upper intermediate' level of both knowledge and use of items.

Table 11. Values of all aggregated items for each subscale.

\begin{tabular}{ccccccc}
\hline Subscale & Men & Level & Women & Level & Total & Level \\
\hline Knowledge & $73.35 \%$ & C1 & $66.12 \%$ & B2 & $68.83 \%$ & B2 \\
\hline Use & $65.70 \%$ & B2 & $62.46 \%$ & B2 & $63.69 \%$ & B2 \\
\hline Source: Own elaboration.
\end{tabular}

There is a difference of $7.23 \%$ between men and women in knowledge, which puts men at a C1 or 'advanced' level of knowledge, while women remain at a B2 or 'upper intermediate' level.

The difference narrows to $3.24 \%$ in the case of use, where both men and women achieve a B2 or 'upper-intermediate' level.

\subsection{Contributions to Open-Ended Questions}

The open-ended questions were included to provide those who took the survey with an opportunity to raise a number of issues that are more difficult to address in a closed questionnaire, which has, in turn, allowed us to enrich the study with more information.

3.3.1. Did You Perceive a Change in Your Own Digital Competence as a Teacher during Confinement? Can You Describe Your 'Before' and 'After'?

Although close to $8 \%$ of the respondents conveyed that their digital teaching competence has not been altered by confinement, many others have stated that it has been altered.

In fact, several relevant elements are expressed in the questionnaire. Firstly, many of the teachers state that they have had to seek new resources that they had not previously considered, in order to provide solutions to new problems caused by confinement.

Furthermore, many of them report that they have been forced to increase the use of tools that they were already familiar with and had not needed to use or had not used regularly. Respondents also commented that the use of ICTs is now here to stay, as a habit of use has been created that they believe will be maintained.

Some respondents also mentioned an increase in collaborative work with colleagues and students, where previously the use of ICTs was more focused on individual work.

Some expressed that, out of necessity, they have lost their 'fear' of using ICTs, and many respondents said that they had to rapidly learn ICTs during the confinement.

\subsubsection{Observations and Suggestions}

In this section, a wide variety of answers were received. There were quite a few complaints regarding the length of the questionnaire and the clarity of the questions. Interesting contributions have also been made, such as teachers feeling abandoned by the administration until they encountered this problem, and that they had to solve the problem without formal training. 
Some respondents expressed their weariness regarding the issue of digital teaching competence, as they do not consider it to be a fundamental element that should be required of teaching staff.

On the other hand, there are also respondents who have expressed appreciation, because they believe the questionnaire has given them an opportunity to reflect on their position in terms of competence, and to rethink their future in digital teaching competence.

\subsubsection{Describe Briefly What Actions You Have Carried Out and What Technologies You} Have Used

A great diversity of responses was encountered in this section. Some respondents said they had used resource repositories to deliver their lessons, such as YouTube and other video or image repositories. Some stated that they used videoconferencing for synchronous classes, using multiple platforms such as Meet, Teams, or Zoom, while others reported using software to record lessons so that they could upload them to platforms or YouTube channels. Some respondents digitized their notes and uploaded them to platforms for the students to download.

The highest number of respondents reported using Google tools, including Classroom as well as other tools included in G-suite.

\subsubsection{What Content Do You Think You Need Specific Training on? Please Answer Briefly}

Respondents have reported a great diversity of training needs in order to improve their digital teaching competence. Some consider that they require training in all of the areas covered in the questionnaire, which indicates that they consider themselves to have a low level of digital teaching competence.

Many respondents also believe that they require training in terms of content creation, especially in audiovisual content, and many have highlighted the need for training in data protection laws and content licensing.

\subsection{Limitations of the Study}

We have presented an original study with the participation of secondary and sixth form teachers who were working at this stage of education during confinement in Spain due to COVID-19, from March to June 2020. Their participation was essential to be able to conduct the study. The final sample size was smaller than expected, since the first research report was to be delivered by the end of June 2020. We believe that this study is a good step towards proposing future research that will include a larger number of participants. This sample is not intended to generalize the results, but it is necessary in order to raise new research objectives.

\section{Conclusions}

The confinement brought about by the COVID-19 pandemic was a complex time for society in general; however, it is worth acknowledging the work of teachers, at a global level, in their rapid adaptation to what has been called Emergency Remote Teaching [6]. This situation "has had effects on the social, political, educational, and economic inequalities that have amplified the effects of the pandemic" [37]. Among the most affected vulnerable communities are low-income families and women [36]. In this context of uncertainty, we can see from their self-perception of their digital teaching competence that secondary and sixth form teachers consider themselves to be ready to move from Emergency Remote Teaching to a teaching model based on blended learning.

This study has allowed for certain conclusions to be drawn, both from a theoretical and a practical perspective. With regard to the objectives set, we can conclude that the main objective has been met; it has been possible to adequately assess the level of digital teaching competence that teachers consider themselves to have in the field of secondary education.

The teachers' self-assessments are quite high for the level that was expected, given the 'noise' that was made in the educational field regarding the limitations of ICTs, and 
the effort that teachers had to make in order to adapt their teaching with the use of ICTs during the COVID-19 pandemic.

We believe that future studies should employ an independent and objective evaluation, which is not based on teachers' own perceptions of their knowledge and use of ICT in education.

From a theoretical standpoint, we conclude that the evolution of the use of ICT-based elements in society has led to the introduction of ICT tools in the education system.

The rapid evolution of the ICT world means that training and knowledge becomes obsolete in a short period of time, which is why it is imperative for teachers to receive ongoing training for digital teaching competence, which should be examined regularly.

In addition, the application of ICTs within the education system was developed merely as a substitute for tools, thus becoming an instrumental element without any true integration of ICT knowledge and pedagogy as required by the TPACK model.

The items assessed to measure digital teaching competence need to be constantly reviewed due to the rapid changes in the ICT world.

It can be stated that, given the importance of education and educational training, and therefore the subject we are dealing with, digital teaching competence, the self-assessment of this competence deserved greater development. Taking a model as general as INTEF's as a reference means that the assessment of this competence loses some rigor for a group as specific as teaching staff. The research conducted, together with other studies with the same objective (but with a different model and instrument), show that the political-educational model of digital competence should be revised. Similarly, the assessment model of digital teaching competence needs to be revised in order to move from a model based solely on self-perceptions to a model based on the complementary implementation of skills such as portfolios [25].

It would also be interesting for official bodies to develop a unified certification, with the same rigor as that of languages, in order to be able to genuinely assess the digital teaching competences. Although the tools highlighted in this study are tested and academically valid, an actual certification system would make it possible to draw a map of the teaching staff.

The following conclusions can be drawn from the empirical part of the study:

Teachers consider themselves to have an upper intermediate level (C1) of both knowledge and use of the tools that define digital teaching competence. This conclusion is similar to the result of another study with similar characteristics to ours [36], with a group of teachers at the secondary school level, which was carried out with a group of teachers in which those at secondary school level comprised $38.3 \%$ of the sample, or 176 participants. It concludes that the higher the level of the stage at which teachers work, the greater the need for digital competence.

In aggregate, of all the items studied, there are only two in which women consider themselves to have more knowledge than men. In the rest of the items, men consider themselves to have more knowledge. Thus, we can state that the digital teaching competence of men is greater than that of women. These differences are also significant, as there is a difference of more than $5 \%$ in 37 items.

With respect to the use of the items studied, the conclusions are similar to those of the knowledge of the items studied. Women report higher use of items than men in only 10 items. However, it should be noted that the differences between men and women are lower in this section; the difference between men and women exceeds $15 \%$ in only 12 items. Similar results have been found in the study with pre-service secondary school teachers by Jimenez-Hernández et al., which uses the DigCompEdu model [38] and another instrument $[39,40]$.

When studying the different areas in which the proposed score can be divided, respondents consider themselves to have an upper intermediate level of knowledge in all areas, which is exactly the same as for their use, although the levels of use are always lower 
than the levels of knowledge. Only in the area of communication do respondents consider themselves to have a high level of knowledge.

Finally, we do not wish to conclude this study without proposing a series of improvements, such as the following:

It has become clear that there is a significant gap between the knowledge and level of use of ICTs, so it can be concluded that, overall and regarding ICT training, teachers are sufficiently trained, but they need tools and motivation to put their knowledge into practice. In other specific areas where teachers do not have the desired knowledge, training should therefore be provided by the administration in order to meet this need.

In the future, it would be interesting to measure digital teaching competence over time, in order to obtain an analysis that would allow us to see how their competence evolves. By maintaining this study over time, we could analyze whether the learning policies for this competence are having an effect, or whether the administration is simply playing to the crowd. It would be interesting to carry out this study from now on, to find out whether the obligatory use of ICTs brought about by COVID-19 will merely become an anecdote, or whether it will change the training paradigm, including, once and for all, true integration of ICTs.

Author Contributions: Conceptualization, J.-M.P.-B. and F.-I.R.-D.; methodology, J.-M.P.-B., F.-I.R.-D. and M.-I.P.-R.; software, F.-I.R.-D. and M.-I.P.-R.; validation, J.-M.P.-B. and F.-I.R.-D.; formal analysis, J.-M.P.-B. and F.-I.R.-D.; investigation, J.-M.P.-B.; resources, M.-I.P.-R.; data curation, J.-M.P.-B.; writing—original draft preparation, J.-M.P.-B., F.-I.R.-D. and M.-I.P.-R.; writing—review and editing, F.-I.R.-D. and M.-I.P.-R.; visualization, J.-M.P.-B.; supervision, F.-I.R.-D.; project administration, M.I.P.-R.; funding acquisition, F.-I.R.-D. and M.-I.P.-R. All authors have read and agreed to the published version of the manuscript.

Funding: This publication has been made possible thanks to funding granted by the Regional Department of Economy, Science and Digital Agenda of the Regional Government of Extremadura and by the European Regional Development Fund of the European Union through the grant reference GR18071.

Institutional Review Board Statement: Not applicable.

Informed Consent Statement: Informed consent was obtained from all subjects involved in the study.

Data Availability Statement: The data presented in this study are available on request from the corresponding author. The data are not publicly available at the participants' requests.

Acknowledgments: To all study survey Spanish teachers-participants during COVID-19 confinement.

Conflicts of Interest: The authors declare no conflict of interest.

\section{References}

1. López-Gil, M.; Bernal, C. El perfil del profesorado en la Sociedad Red: Reflexiones sobre las competencias digitales de los y las estudiantes en Educación de la Universidad de Cádiz. IJERI Int. J. Educ. Res. Innov. 2019, 11, 83-100.

2. Gisbert, M.; González, J.; Esteve, F.M. Competencia digital y competencia digital docente: Una panorámica sobre el estado de la cuestión. Rev. Interuniv. Investig. Tecnol. Educ. 2016, 74-83. [CrossRef]

3. The Udemy Business. 2020 Workplace Learning Trends Report: The Skills of the Future. Available online: https: / /info.udemy. com/rs/273-CKQ-053/images/2020_Workplace_Learning_Trends_Report.pdf (accessed on 22 July 2021).

4. Vuorikari, R.; Punie, Y.; Carretero, S.; Van Den Brande, L. DigComp 2.0: The Digital Competence Framework for Citizens; European Comission: Brussels, Belgium, 2016; ISBN 978-92-79-58876-1.

5. Álvarez, J.F. La Formación en TIC del profesorado de Secundaria del Estado Español. Un análisis desde la percepción docente. Univ. Tarraconensis. Rev. Ciènc. l'Educ. 2016, 1, 67. [CrossRef]

6. Hodges, C.; Moore, S.; Lockee, B.; Trust, T.; Bond, A. The Difference between Emergency Remote Teaching and Online Learning. Educause 2020, 27, 1-12.

7. Moorhouse, B.L. Adaptations to a face-to-face initial teacher education course 'forced' online due to the COVID-19 pandemic. J. Educ. Teach. 2020, 46, 609-611. [CrossRef]

8. Davies, L.; Bentrovato, D. Understanding Education's Role in Fragility. Synthesis of Four Situational Analyses of Education and Fragility: Afghanistan, Bosnia and Herzegovina, Cambodia, Liberia; UNESCO: Paris, France, 2011; 65p. 
9. Trujillo Sáez, F.; Fernández Navas, M.; Montes-Rodríguez, R.; Segura Robles, A.; Alaminos Romero, F..; Postigo-Fuentes, A.Y. Panorama de la Educación en España tras la Pandemia de COVID-19: La Opinión de la Comunidad Educativa; FAD: Madrid, Spain, 2020; 176p.

10. Portillo Peñuelas, S.A.; Castellanos Pierra, L.I.; Reynoso González, Ó.U.; Gavotto Nogales, O.I. Enseñanza remota de emergencia ante la pandemia COVID-19 en Educación Media Superior y Educación Superior. Propósitos Represent. 2020, 8, 589. [CrossRef]

11. Galindo, D.; García, L.; García Sánchez, R.; González Flores, P.; Hernández Cerrito, P.C.; López Acosta, M.; Luna, V.; Moreno Arellano, C.I. Recomendaciones didácticas para adaptarse a la enseñanza remota de emergencia. Rev. Digit. Univ. 2020, 21, 1-13. [CrossRef]

12. Aras, B.; Ramesh, S. Emergency remote teaching in a time of global crisis due to Coronavirus pandemic. Asian J. Distance Educ. 2020, 15, 1-6.

13. Toquero, C.M. Emergency remote education experiment amid COVID-19 pandemic. Int. J. Educ. Res. Innov. 2020, 15, 162-176. [CrossRef]

14. Krumsvik, R. Situated learning in the network society and the digitised school. Eur. J. Teach. Educ. 2009, 32, 167-185. [CrossRef]

15. Castañeda, L.; Esteve, F.; Adell, J. Why rethinking teaching competence for the digital world? Rev. Educ. Distancia 2018, 56, 1-20. [CrossRef]

16. Piñón Howlet, L.; Sapién Aguilar, A.; Gutierrez-Diez, M.d.C. Autoevaluación de docentes en competencias tecno-pedagógicas para la elaboración de materiales didácticos virtuales. Publicaciones 2019, 49, 161-177. [CrossRef]

17. Díaz-Barriga, Á. TIC en el trabajo del aula. Impacto en la planeación didáctica. Rev. Iberoam. Educ. Super. 2013, 4, 3-21. [CrossRef]

18. Revelo, J.; Revuelta-Domínguez, F.; Gonzále-Pérez, A. Modelo de integración de la competencia digital del docente universitario para su desarrollo profesional en la enseñanza de la matemática. Rev. Educ. Mediat. TIC 2018, 7, 196-224.

19. Campos Soto, A.; Trujillo Torres, J.M.; Ruiz Palmero, J.; Sánchez Rodríguez, J. Percepciones sobre la implementación de las TIC en la autonomía de los IES de la Ciudad Autónoma de Melilla. Publicaciones 2018, 48, 213-233. [CrossRef]

20. INTEF. Marco Común de Competencia Digital Docente. Available online: https://aprende.intef.es/sites/default/files/2018-05/ 2017_1020_Marco-Común-de-Competencia-Digital-Docente.pdf (accessed on 22 July 2021).

21. Boudet, J.M.F. Evaluación de la competencia digital docente en la comunidad autónoma de Aragón. Rev. Electron. Investig. Educ. 2017, 19, 73-83. [CrossRef]

22. Cervera, M.G.; Cantabrana, J.L.L. Professional development in teacher digital competence and improving school quality from the teachers' perspective: A case study. J. New Approaches Educ. Res. 2014, 4, 115-122. [CrossRef]

23. Fernández-Cruz, F.J.; Fernández-Díaz, M.J.; Rodríguez-Mantilla, J.M. Design and validation of an instrument to measure teacher training profiles in information and communication technologies. Rev. Esp. Pedagog. 2018, 76, 247-270. [CrossRef]

24. Sanabria, A.C.O. La educación para la competencia digital en los centros escolares: La ciudadanía digital. Rev. Latinoam. Tecnol. Educ.-Relatec 2014, 13, 1-16. [CrossRef]

25. Tourón, J.; Martín, D.; Navarro Asencio, E.; Pradas, S.; Ínigo, V. Validacion de constructo de un instrumento para medir la competencia digital docente de los profesores (CDD). Rev. Esp. Pedagog. 2018, 75, 25-54. [CrossRef]

26. Valdivieso, T.S.; Gonzáles, M.Á. Competencia Digital Docente: ¿Dónde Estamos? Perfil del docente de educación primaria y secundaria. El caso ce Ecuador. Pixel-Bit Rev. Medios Educ. 2016, 49, 57-73. [CrossRef]

27. Valverde, J.; Garrido, M.; Fernández, R. Enseñar y aprender con tecnologías: Un modelo teórico para las buenas prácticas educativas con TIC. In Buenas Prácticas de Enseñanza con TIC; De Pablos, J., Ed.; Universidad de Salamanca: Salamanca, Spain, 2010; Volume 11, pp. 203-229; ISBN 9780080448947.

28. Cabero, J.; Roig, R.; Mengual, S. Conocimientos tecnológicos, pedagógicos y disciplinares de los futuros docentes según el modelo TPACK [Technological, pedagogical, and content knowledge of future teachers according to the TPACK model]. Digit. Educ. Rev. 2017, 32, 85-96.

29. Graham, J.; Plumptre, T.; Amos, B. Principles for Good Governance in the 21st Century; Policy Brief No. 15; Institute on Governance: Ottawa, ON, Canada, 2003; 9p. Available online: https://unesdoc.unesco.org/ark:/48223/pf0000191504/PDF/191504eng.pdf. multi (accessed on 22 July 2021).

30. Krauskopf, K.; Foulger, T.S.; Williams, M.K. Prompting teachers' reflection of their professional knowledge. A proof-of-concept study of the Graphic Assessment of TPACK Instrument. Teach. Dev. 2018, 22, 153-174. [CrossRef]

31. Cabero, J.; Marín, V.; Castaño, C. Validation of the application of TPACK framework to train teacher in the use of ICT. ATTIC Rev. d'Innov. Educ. 2015, 14, 13-22. [CrossRef]

32. Silva, J.; Revuelta, F. Modelos cerrados y abiertos para evaluar las competencias digitales. Didasc@laia. Didact. Educ. 2015, 7, 111-128.

33. Kampylis, P.; Punie, Y.; Devine, J. Promoting Effective Digital-Age Learning-A European Framework for Digitally-Competent Educational Organisations; Publications Office of the European Union: Luxembourg, 2015.

34. Caena, F. Supporting Teacher Competence Development for Better Learning Outcomes; European Comission: Brussels, Belgium, 2013.

35. Pérez, A.; Rodríguez, M. Evaluación de las competencias digitales autopercibidas del profesorado de Educación Primaria en Castilla y León (España). Rev. Investig. Educ. 2016, 34, 399-415. [CrossRef]

36. Portillo, J.; Garay, U.; Tejada, E.; Bilbao, N. Self-Perception of the Digital Competence of Educators during the COVID-19 Pandemic: A Cross-Analysis of Different Educational Stages. Sustainability 2020, 12, 10128. [CrossRef]

37. United Nations. The Sustainable Development Goals Report 2020. Available online: https://unstats.un.org/sdgs/report/2020 /The-Sustainable-Development-Goals-Report-2020.pdf (accessed on 22 July 2021). 
38. Redecker, C. European Framework for the Digital Competence of Educators: DigCompEdu. Available online: https:// publications.jrc.ec.europa.eu/repository/bitstream/JRC107466/pdf_digcomedu_a4_final.pdf (accessed on 22 July 2021).

39. Jiménez-Hernández, D.; González-Calatayud, V.; Torres-Soto, A.; Mayoral, A.M.; Morales, J. Digital competence of future secondary school teachers: Differences according to gender, age, and branch of knowledge. Sustainability 2020, $12,9473$. [CrossRef]

40. García Varcácel, A.; Martín del Pozo, M. Analysis of the digital competences of graduates of university degrees to be a teacher. Rev. Latinoam. Tecnol. Educ.-Relatec 2016, 15, 155-168. [CrossRef] 